\title{
VZPOSTAVLJANJE VARNE NAVEZANOSTI KOT TEMELJ DELA S POSAMEZNIKI, PARI IN DRUŽINO
}

Prof. dr. Tomaž

Erzar

Dr. Katarina

Kompan Erzar

Teološka fakulteta

Univerze $v$ Ljubljani

\section{POVZETEK}

Teorija navezanosti je eden od mejnikov v raziskovanju in razumevanju dela z ljudmi. Razumevanje odnosov kot vzajemnih, torej dvostranskih, in kot razmerij, v katerih gre za regulacijo afektov, odpira povsem nov pogled na različne oblike dela z ljudmi, tako klinične kot preventivne in izobraževalne. Raziskave in dolgoletna terapevtska praksa kažejo, da je ustrezna oblika pomoči oziroma okvir za kakovostno delo z ljudmi samo tista, ki zagotavlja varnost. Torej varno zavetje, kadar posamezniki prihajajo iz nevarnih okolij in razmer ter izkušenj, in trdno izhodišče za posameznike, ki želijo razširiti, preoblikovati in na novo vzpostaviti nekatere vidike svojega življenja in odnosov. V našem prispevku bomo predstavili tri temeljne premike v pojmovanju tega dela in opisali primere konkretnih praks oziroma novih oblik dela, ki iz teh premikov izhajajo. Ti trije mejniki so: drugačno pojmovanje otroka (otrok kot odvisen od odraslih), drugačno pojmovanje starševstva oziroma na otroka usmerjeno starševstvo ali notranje starševstvo in drugačno delo z družino kot sistemom, ki ga zaznamujejo globoke vezi navezanosti, od katerih je v veliki meri odvisno, kako se bosta sistem in posameznik znotraj sistema razvijala ter kako morajo biti oblikovane intervence, kadar gre za sisteme, ki temeljijo na sramu, strahu in nevarnih oblikah navezanosti.

Ključne besede: teorija navezanosti, delo z ljudmi, relacijska perspektiva, sistem, varnost.

\section{ESTABLISHMENT OF SAFE ATTACHMENT AS THE BASIS FOR WORK WITH INDIVIDUALS, COUPLES AND FAMILIES - ABSTRACT}

Theory of attachment has radically changed the way we understand human relationships and work with people today. Understanding relationships as processes of mutual affect regulation has opened the door to a new generation of approaches to clinical work, prevention and education. Therapeutic research and practical work with clients show that providing relational safety, or a secure base, is a necessary precondition for working with vulnerable populations. In the article three fundamental shifts in our understanding of therapeutic and preventive work are presented and described with the help of examples of good practice. First, a child is dependent on adult caregivers for her/his emotional and physical well-being; second, parenting starts from the inside out, and third, family relationships are an intergenerational attachment-driven system. Designing effective interventions in cases of shame- and fear-based family systems requires paying special attention to this aspect of insecure attachment.

Keywords: attachment theory, clinical work, relational perspective, system, secure base.

UDK: 615.851

V prispevku se bomo osredotočili na vidike terapevtskega dela z družinami, starši in otroki, ki omogočajo vzpostavitev, razvoj in ohranjanje varnih odnosov pripadnosti. $\mathrm{Z}$ opiranjem na teorijo navezanosti in na oblike psihoterapije, ki izhajajo iz nje, bomo poskušali odgovoriti na vprašanje, kaj varni odnosi pomenijo $\mathrm{v}$ razvoju posameznika, družine in družbe ter kakšne implikacije ima globinsko poznavanje in razumevanje odnosov za širši družbeni kontekst dela z ljudmi. Predstavili bomo terapevtska izhodišča in intervence, ki omogočajo oblikovanje ustreznih programov za delo z družinami v različnih razvojnih obdobjih, in $\mathrm{v}$ sklepnem delu prispevka opisali nekaj različnih oblik dela, ki smo jih razvili pri nas. 


\section{TEORIJA NAVEZANOSTI IN PSIHOTERAPIJA: DRUGAČNO POIMOVANJE OTROKA}

Terapevtska in razvojna stroka sta se $\mathrm{v}$ prejšnjem stoletju kar nekaj desetletij ukvarjali z vprašanjem, kaj je jedro zdravega in čustveno bogatega razvoja posameznika. Ob tem sta prišli do spoznanja, da osebnostnega razvoja ni mogoče niti spodbuditi niti razumeti, ne da bi poudarili ključno vlogo varne navezanosti med otrokom in starši ter vlogo $\mathrm{v}$ odraslih odnosih pridobljene varne navezanosti, ki omogoča celotnemu družinskemu sistemu globinsko preoblikovanje notranjih nefunkcionalnih vzorcev iskanja čustvene bližine in opore (Kobak, 1999). Ključne korake $\mathrm{v}$ smeri relacijskega in zlasti nenagonskega pojmovanja otrokovega razvoja je že v 50. letih naredil John Bowlby, angleški psihiater, utemeljitelj teorije navezanosti, in jih kasneje sistematično opisal v trilogiji »Attachment and Loss « (Bowlby, 1969, 1973, 1980). S sodobnimi nevropsihološkimi raziskavami o organskem delovanju možganov so te ugotovitve dobile tudi naravoslovno podlago ter omogočile integracijo prej na videz razpršenih spoznanj različnih strok (psihoanalize, sistemske psihoterapije, razvojne psihologije, etologije, kibernetike).

Med teorijo navezanosti in psihoterapijo za starše in otroke obstajata torej podobnost in tesna zgodovinska povezanost. Prvič, obe poudarjata ključni pomen odnosa med materjo in otrokom v prvih treh letih življenja za zdrav čustveni razvoj otroka. Drugič, oba pristopa sta se uveljavila v 70. letih kot nadaljevanje psihoanalitičnega zdravljenja in psihoanalitičnih pojmovanj. Psihoterapija za starše in otroke je že sredi 60. let dobila močne teoretične in praktične spodbude, pri čemer imamo v mislih zlasti dela Bowlbyja, Winnicotta in Anne Freud. Teme in ideje teh sicer različnih avtorjev so si bile vendarle v grobem zelo podobne: otrok potrebuje varen odnos s starši, odsotnost teh odnosov je za otroka škodljiva, škodljiv pa je za otroka lahko tudi vpliv, ki ga ima notranji svet staršev na njihov odnos do otroka. Pri vseh zasledimo temeljni premik od klasičnega psihoanalitičnega pristopa, v katerem so starši žrtve otrokovih agresivnih in erotičnih nagnjenj, k pojmovanju, da je otrok marsikdaj zgolj transferni objekt za projekcije staršev, ki izhajajo iz njihovega otroštva.

V ZDA ta prehod od klasične psihoanalitične drže do otroka k teoriji navezanosti najbolje pooseblja delo Selme Fraiberg (1918-1981), ki je v 70. letih na univerzi v Michiganu razvila samostojni terapevtski program za pomoč staršem in otrokom. Pomembna novost v programu je bila navzočnost otroka na terapevtskih srečanjih, podprta z ugotovitvijo, da poročanje staršev o otroku ne more nadomestiti neposrednega opazovanja, pri katerem lahko terapevt opazi tudi tiste otrokove lastnosti, čustvene vsebine, oblike vedenja ali razvojne momente, ki bi jih starši nehote zakrili ali prikazali popačeno. Terapevt pri svojem delu izhaja iz spoznanja, da otrokov zdravi razvoj zavirajo podobe in občutja, ki izhajajo iz otroštva staršev in nimajo zveze z otrokovim trenutnim življenjem in doživljanjem: »Otrok je za starše le zastopnik oseb iz njihove preteklosti ali zastopnik nekega vidika v doživljanju sebe pri starših, ki je bil izrinjen ali zanikan.« (Fraiberg, 1980: 61.) Bistvena lastnost odnosov, kjer starši otroka dojemajo popačeno, je, da ga doživljajo kot čustveno veliko močnejšega in nasilnejšega, kot je $\mathrm{v}$ resnici, saj se jim ob otroku prebujajo občutja nemoči in strahu, ki so jih doživljali ob svojih starših. Otroka sicer zavestno in namerno ne doživljajo kot lastne starše, a se kljub temu nanj odzivajo povsem obrambno, tako da nanj usmerjajo jezo in bes, ki ju niso mogli pokazati svojim staršem. Iz tega popačenega dojemanja otroka, ko ta $v$ očeh in doživljanju staršev naenkrat postane zelo močan vir številnih težav, ki jih imajo odrasli v svojih družinah in odnosih, je izhajalo tudi dolgotrajno psihoanalitično prepričanje, da otrok v civilizirani svet prepovedi in odpovedi 
vnaša nevzdržna občutja in da so starši prve nemočne žrtve teh občutij.

Podobno kot je individualna psihoterapija dosegla presenetljive spremembe $\mathrm{v}$ psiholoških simptomih in destruktivnih vzorcih vedenja odraslih ljudi, ko so se ti lahko spominjali ključnih dogodkov iz svojih otroških let ter podoživeli z njimi povezano bolečino, strah, jezo in nemoč, je v 70. in 80. letih tudi psihoterapija za starše in otroke sprožila neverjetne spremembe v doživljanju otroka pri starših in posledično tudi spremembe $\mathrm{v}$ otrokovem vedenju. Starši so lahko na terapevtskih srečanjih svojo negotovost, preplavljenost s krivdo ali izbruhe besa in celo sovraštva do otroka povezali z lastnimi izkušnjami ob svojih starših ter svojemu otroku s tem omogočili, da ni bil več tarča pripisovanja te vloge in reaktivnega vedenja, ampak je bil deležen nove pozornosti, novoodkrite nežnosti in sočutja. Nemirni, umaknjeni ali jezni otrok se je spremenil v živahnega, zadovoljnega in ljubljenega. Starše je $\mathrm{v}$ tem procesu najbolj pomirilo spoznanje, da jih ima otrok iskreno rad in jih potrebuje. Na podlagi varnosti, ki jim jo daje ta notranji občutek, so laže sprejeli, da je velik del problema nastal zato, ker so oni napačno dojemali otroka, k čemur so jih silili vzorci iz otroštva, ko so oni sami večkrat doživljali, da jih starši nimajo zares ali dovolj radi. Tako so svoj sedanji strah, jezo in nemoč ob tem, da jih otrok nima rad ali da jih zavrača in se vede kot »tiran «, prevedli v svoj nekdanji otroški strah, jezo in nemoč, ko

Ključno za spremembo drže staršev do otroka je bilo, da so premagali svojo trenutno frustracijo, kar se je zgodilo takrat, ko so lahko kljub nemoči sebe vendarle doživeli kot učinkovite dejavnike $\mathrm{v}$ vsakodnevnem odnosu $\mathrm{z}$ otrokom, še več, kot ključne in edine dejavnike, ki so ne samo potrebni in nujni, ampak celo zaželeni in ljubljeni (Erzar, Kompan Erzar, v tisku). so doživljali, da so prepuščeni sami sebi, da nikomur ni mar zanje in da ne morejo narediti ničesar, da bi kaj spremenili in starše omehčali.

\section{NA OTROKA USMERJENO STARŠEVSTVO ALI NOTRANJE STARŠEVSTVO}

Terapevt pomaga staršem do bolj naklonjene in manj tesnobne drže do otroka s tem, da ustvari zanje čustveno varen in naklonjen prostor (Hughes, 2009). To stori tako, da najprej pri sebi poišče ustrezno držo do starševske patologije oziroma da omogoči staršem, da poiščejo vir stisk in tesnobe $\mathrm{v}$ svojem otroštvu in odraslosti ter prepoznajo, kateri del njihove notranjosti prebuja njihov otrok s svojimi specifičnimi značilnostmi. Daniel Siegel v svojem delu »Parenting from the inside out « (2003) pravi, da vsak otrok v starših prebuja tista čutenja, ki so zanje najtežja. Če torej terapija staršem pomaga ozavestiti položaj in zdržati s temi čustvi ter jih povezati z njihovo preteklostjo, potem bo tudi njihovo soočanje $\mathrm{z}$ otrokovim vedenjem in spodbujanje zdravega razvoja steklo brez nepotrebnih stisk in pritiskov. To pa se lahko zgodi takrat, ko terapevt staršem najprej omogoči razumevanje otroka, in razumevanje tega, da globina in moč stiske, ki se jim prebuja ob otroku, govori o njihovi sposobnosti reguliranja stresa in o starševstvu njihovih staršev. Pristop, ki temelji na zaupanju v starševsko ljubezen do otroka, ima za neposredni rezultat prav prebuditev ali oživitev te ljubeče drže pri starših. V zvezi s tem se pred terapevta postavlja naloga, da s pomočjo lastnega doživljanja najprej pri sebi prepozna ovire za naklonjenost do otroka in staršev, nato pa te ovire prevede $\mathrm{v}$ doživljajski svet staršev in poskuša skupaj z njimi prepoznati te ovire $\mathrm{v}$ odnosih v njihovih izvornih družinah. Izkušnja tega naklonjenega raziskovanja preteklosti deluje korektivno za vse vključene člane družine, saj se na tej poti izza strahu in jeze, ki sta dva normativna odgovora na neustrezno starševstvo, prebijejo na plan pristna skrb, razumevanje in 
sočutje, ki so značilni za ustrezno starševstvo (Erzar in Kompan Erzar, v tisku).

Eno najtežjih čustvenih stanj, ki dostikrat postane vir stisk in težav starševstva, je osramočenost oziroma sram. Sram psihofiziološko pomeni tisto stanje organizma, ki se pojavi takrat, ko posameznik ob svoji iniciativi, dejanju, besedi, pogledu, drži doživi avtomatičen in neposreden odpor in neodobravanje drugih. Ta odziv v telesu sproži vzburjenje parasimpatičnega živčevja, ki povzroči takojšnjo ustavitev vseh telesnih motoričnih aktivnosti in mlahavost telesa. Sram ima namreč funkcijo preprečevanja aktivnosti, ki bi ogrozile posameznikovo preživetje, tudi v socialnem smislu. Sram je tako neposredno povezan z iniciativo in je eden ključnih afektov, čutenj, ki omogoča regulacijo in preoblikovanje iniciativ, impulzov v socialno in fizično sprejemljive oziroma varne (Schore, 1994). Ključni preobrat v starševstvu torej nastopi takrat, ko starši prek obvladovanja svojih impulzov, ki jih $\mathrm{v}$ njih prebudi otrok (ko se počutijo osramočene, ker se je v trgovini vrgel na tla in kriči; ko jih je sram, ko pokaže jezik teti; ko potegne za žico in mu grozi, da bo nanj padel televizor ...), zmorejo ohraniti stik z otrokom in otroka zavarovati pred sovražnimi pogledi, fizičnimi poškodbami in pretirano izčrpanostjo. Ob tem pa sami začutijo ponos, moč in povezanost $\mathrm{z}$ otrokom, ki posledično umiri tudi njih (Kompan Erzar, Poljanec, 2010).

Ta preboj je praviloma povezan $\mathrm{z}$ občutjem sramu in osramočenosti, ki je $\mathrm{v}$ sedanjosti največkrat povezan s tem, da se starši počutijo nesposobne ali izpostavljene, ker so bili prisiljeni poiskati pomoč, ali ponižane, ker so bili »zasačeni« pri dejanjih, ki so sramotna. Korenine tega sramu pa segajo v njihove izkušnje navezovanja $\mathrm{v}$ otroštvu, $\mathrm{v}$ katerih je bila otrokova iniciativa pri iskanju opore in pomoči ustavljena s sramotenjem ali poniževanjem. Ko terapevt spodbuja starše k novi drži in razmišljanju o njihovih otroških izkušnjah, se v njih naravno prebudi odpor kot izraz jeze in protesta zoper tako sodelovanje in spodbuja- nje iniciativnosti. Starši pri tem doživljajo, da so v sodelovanje prisiljeni oziroma da jim je ta situacija vsiljena, podobno kot jim je bilo nekoč vsiljeno sodelovanje z njihovimi starši, ki je bilo utemeljeno na ustrahovanju in prisili. Ta odpor terapevt premaga $\mathrm{z}$ razumevanjem in sprejemanjem jeze in protesta, $s$ čimer da temu izrazu vso upravičenost. Zmanjšanju jeze praviloma sledi občutek izpostavljenosti ali sramu, se pravi globalno stanje brez zaščite, ki jo dajal bodisi strah bodisi jeza in odpor, pa tudi stanje, ki vodi nazaj v pasivnost in status quo. Od tod terapevtova previdnost in postopnost, kajti za sramom je občutljivi otroški občutek zase in za lastno učinkovitost (prim. stopnje doživljanja sebe in drugih) (Erzar, Kompan Erzar, v tisku). V splošnem lahko rečemo, da je preoblikovanje notranjega delovnega modela pri starših tesno povezano s tem, kako dejavni bodo $\mathrm{v}$ trenutkih popolne ranljivosti in izpostavljenosti, ki nastopijo v procesu terapije in ki jih bodo začutili tudi v svojem odnosu do otroka in partnerja.

Odpor do razumevanja otroka kot nekoga, ki je odvisen od staršev (in ne obratno, kakor je trdila psihoanaliza), je zelo pripomogel $\mathrm{k}$ temu, da je bila teorija navezanosti v terapevtskih vrstah razumljena kot obroben pojav, kot parcialna teorija o nekem vidiku otrokovega razvoja, ki ne zadeva področja drugih, bolj odraslih motivacijskih sistemov, kot so spolnost, agresija ali moč. Poudarjanje varnosti se jim je zdelo z vidika kliničnega dela z odraslimi preozko, zato so imeli teorijo za akademsko, raziskovalno, ne pa za klinično uporabno. Šele postopoma sta se psihoanaliza in klinično delo z odraslimi odprla vplivom in idejam, ki jih je zagovarjala teorija navezanosti: upoštevanje navezanosti kot samostojnega motivacijskega sistema, pomen dejanskih življenjskih izkušenj in dogodkov, opazovanje vedenja in neverbalnih sporočil ter upoštevanje intersubjektivne narave nezavednih procesov. Pobudo pri razvijanju psihoanalitičnih smeri so v 80 . in 90 . letih prevzeli razvojno šolani raziskovalci, ki so 
bili hkrati psihoanalitično formirani terapevti, denimo Joe Lichtenberg, Peter Fonagy, Robert Emde, Daniel Stern in Karlen Lyons-Ruth.

Ključna razlika na ravni terapevtske prakse se pojavi pri tem, kako je v obeh pristopih, analitičnem in navezanostnem, razumljena vloga terapevta. Stališče teorije navezanosti je, da terapevtova naklonjena in raziskovanju namenjena drža že v odnosu do staršev odpira možnost nove navezovalne strategije. Jedro te drže je varna regulacija strahu, jeze, sramu in iskanja bližine. Terapevt deluje kot varno izhodišče preiskovanja lastnega doživljanja v sedanjosti in preteklosti: to delo prebuja, kot smo videli, odpor, krivdo, izmikanje kazni in osramočenost, toda ker terapevt ob tem ne išče varnosti zase, ampak še vedno deluje kot varno zatočišče, omogoča ponoven zagon preiskovanja in poskušanja. Nova iniciativnost staršev v odnosu do otroka je razumljena kot posledica te ponovno obujene iniciative v odnosu med terapevtom in starši. Ta iniciativa seveda ni brez ovir, saj je treba na poti preiskovanja jezo slej ko prej preusmeriti z otroka nazaj na lastne starše, kar nehote odpre problem lojalnosti in zvestobe. Terapevt tudi tu deluje kot varno zatočišče in varno izhodišče, kolikor omogoča staršem, da na podlagi nove naklonjene drže do otroka, do samih sebe in do njega kot terapevta nadaljujejo preiskovanje okoliščin lastnega otroštva. $\mathrm{Ob}$ tem je pomembno, da starši razumejo, da je bila njihova največkrat nekritična in čustveno neupravičena lojalnost do staršev v nekem obdobju njihovega razvoja in poslavljanja od doma vendarle upravičena, saj je bila edina možnost za ohranjanje vezi med njimi kot otroki in njihovimi starši. Še zlasti če vemo, da je podoba o starših kot popolnih in ljubečih skrbnikih toliko bolj močna in idealna, kolikor več je bilo v odnosu med njimi in otrokom izogibanja in zavračanja bližine. V tem smislu bi lahko rekli, da je bila stara lojalnost v izvorni družini staršev lojalnost brez sočutja in razumevanja, medtem ko je nova lojalnost do njihovega otroka in samih sebe zgrajena na sočutnem odnosu do otroške stiske.
Bistveni poudarki terapevtskega dela s starši z vidika teorije navezanosti so torej naslednji: pozornost se namenja procesom navezovanja $\mathrm{v}$ sedanji in izvorni družini ter njihovemu ovrednotenje s stališča otrokovih potreb; pozornost se namenja dejanskim otrokovim izkušnjam ločitve, izgub, zlorab, prikrajšanosti in zanemarjanja; pozornost se namenja opazljivim potezam otrokovega vedenja v odnosu do staršev, zlasti čustveni plati teh odnosov in tega vedenja $v$ dejanski terapevtski situaciji »tu in zdaj«; pozornost se namenja povečanju materinske občutljivosti in odzivnosti; pozornost se namenja strategijam izmikanja, izogibanja in minimaliziranja stiske ter drugim strategijam, ki delujejo kot obramba pred tesnobo, strahom ali navali jeze. V tem pogledu lahko rečemo, da je teorija navezanosti povsem na novo ovrednotila terapevtsko delo, ne le s starši in otroki, ampak posledično tudi z odraslimi.

\section{PSIHOTERAPIJA DRUŽIN: DRUGAČNO DELO Z DRUŽINO}

Če otroke razumemo kot odvisne in vzajemno povezane $\mathrm{z}$ odraslimi skrbniki, odrasle kot posameznike, ki jih povezujejo vzajemna regulacija čustvenih stanj in afektov, prek katere vzpostavljajo nove odnose varne navezanosti, ki je v svojem otroštvu niso mogli razviti, ter starše kot posameznike, ki ob otroku marsikdaj sploh prvič pridejo v stik s svojo notranjostjo, potem se nam odpre tudi dosti bolj kompleksna in razvejena čustvena podoba in razumevanje družine. Temeljne predpostavke družinske terapije, ki še ni eksplicitno vključevala teorije navezanosti, ob integraciji spoznanj o navezanosti dobijo precej globlji pomen. Zato so tudi intervence, ki jih taka drža omogoča, usmerjene hkrati v nevropsihološke zakonitosti delovanja možganov ter medosebno dinamiko odnosov v družini in vzdušje, ki ga družina kot celota ustvari v terapevtski pisarni (Kompan Erzar, 2008).

Zbližanje med teorijo navezanosti in kliničnim delom $\mathrm{z}$ družinami se je začelo $\mathrm{v}$ 80. letih prejšnjega stoletja v Ameriki, kar se je videlo v številnih programih za pomoč socialno ogroženim družinam in otrokom iz teh družin. Med te 
programe sodi tudi tisti, ki ga je razvila Selma Fraiberg v Ann Arborju (Michigan), nadaljeval pa se je v San Franciscu z imenom Infant-Parent Program (IPP). Namenjen je bil socialno ogroženim družinam, za katere so bili značilni pomanjkanje izobrazbe pri starših, brezposelnost, stanovanjski problemi, duševne motnje, zloraba drog in nasilje bodisi v družini bodisi na ulici. Otroke so na terapijo napotile svetovalne in socialne službe, sodišča, bolnišnice, pediatri, patronažne službe ali nevladne organizacije (Erzar, Kompan Erzar, v tisku). V teh programih so najbolje napredovali otroci, pri katerih se je vključila vsa družina in je bila pripravljena sprejeti konkretne spremembe ter dodatne oblike zdravljenja, kadar je bilo potrebno (denimo zdravljenje alkoholizma, duševnih bolezni ...). Učinek se je torej pokazal pri vsej družini ali pa program dolgoročno ni dosegel želenega uspeha niti pri otroku. Naslednja ugotovitev, ki je bila za tisti čas presenetljiva, je bila, da se proces sočutnega razumevanja in prepoznavanja potreb odvija vzporedno oziroma hkrati v odnosu med terapevtom in starši ter starši in otrokom. Torej ne glede na to, ali je šlo pri otroku za zaostanek v razvoju, depresivnost, ločitveno tesnobo, pretirane strahove, besne izpade, raztresenost, impulzivnost ali slabo obvladovanje vedenja, se je to vedenje spremenilo izključno takrat, ko je terapevtu uspelo zmanjšati stres pri starših. Zato je bilo treba družinsko terapijo in delo $\mathrm{z}$ otrokom nujno dopolniti tudi s terapijo staršev, torej z delom na partnerskem odnosu in na odnosu med staršema.

Druga veja se je lotila problematike tveganega materinstva in nasilja oziroma oblikovanja programov za otroke, ki so odraščali kot priče nasilja nad svojimi materami. Eden takih programov za otroke iz nasilnih družin, natančneje za otroke, ki so bili priče nasilnemu vedenju do svojih mater, imenovan Child Trauma Research Project ali CTRP, je nastal v San Franciscu. V Minnesoti pa so v začetku 90. let začeli izvajati preventivni program za matere, ki so rodile prvega otroka (Steps Toward Effective,
Enjoyabe Parenting ali STEEP), in za bodoče matere iz revnih družin, ki so jih poleg zelo zgodnjega materinstva spremljale še druge težave: slaba izobrazba, socialna izoliranost, slabi odnosi z domačo družino (Erickson in drugi, 1992). Sodelujoči terapevti so ugotovili, da je bilo za mlade matere, ki so se vključile v program, zelo pomembno, da so se lahko navezale na eno osebo, kar je bistveno pripomoglo $\mathrm{k}$ večjemu občutku varnosti in zaupanju (Erzar, Kompan Erzar, v tisku).

Ob izvajanju teh programov se je spontano razvilo tudi sodelovanje različnih socialnovarstvenih in zdravstvenih služb. Tako so bili na primer v program za pomoč ogroženim družinam konec 80 . let prejšnjega stoletja $\mathrm{v}$ New Yorku že vključeni tako socialni delavci kot psihoterapevti, psihiatri, defektologi, logopedi in psihologi. Namen je bila prilagojena pomoč družinam, ki ne zmorejo obiskovati različnih ustanov. Program je vključeval svetovanje na domu, pomoč pri vsakodnevni logistiki in uporabljanju socialnih storitev (Cicchetti in Toth, 1987). Taki programi se razvijajo tudi pri nas. Program zgodnjih intervenc v okviru MDDSZ od leta 2011 izvaja Frančiškanski družinski inštitut v Ljubljani.

Pomembno področje, ki sodi $\mathrm{v}$ ta sklop in izhaja neposredno iz razumevanja družinske dinamike kot dinamike, ki jo poganja mehanizem navezanosti, je delo z rejniškimi družinami. Otroci, ki so bili zaradi zlorabe ali zanemarjanja nameščeni v rejniške družine, so bili v New Orleansu skupaj z rejniki in biološkimi starši vključeni v program, katerega cilj je bil iskanje najhitrejše poti do varne navezanosti za otroke do čertega leta, sestavljen pa je bil iz obiskov na domu pri bioloških starših in rejnikih, iz ocene odnosa do otroka pri enih in drugih, poročanja sodiščem ter izdelave načrta pomoči (Larrieu in Zeanah, 2004). Temeljil je na predpostavki, da otrok v odraslih praviloma prebudi starševsko držo in da umanjkanje te drže pomeni resno motnjo, ki terja terapevtsko obravnavo $\mathrm{z}$ vidika medgeneracijskega 
prenosa navezovanja, pri čemer so dopustili možnost, da so vzroki tudi v otroku ali okolju oziroma da gre za kombinacijo več vzrokov. Pokazalo se je, da je varna navezanost lastnost odnosa in da ima lahko otrok z različnimi skrbniki različno kakovostne odnose. Skozi te programe se je kot zelo smiselno in utemeljeno pokazalo tudi vključevanje sodišč, saj so čustveno dobro pripravljene in soglasno dogovorjene rešitve močno olajšale sodne postopke. Postopoma so se razvili tudi učni centri za starše in rejnike, katerih cilj je bil, da prek razumevanja in poznavanja mehanizma navezanosti preoblikujejo dotedanje neuspešne poskuse sodelovanja in sporazumevanja med starši in otrokom. Ta cilj je bil dosežen s povečanjem občutka učinkovitosti pri starših in otroku, v prvi vrsti učinkovitosti v medsebojnih interakcijah, skupnem načrtovanju in pogajanju, nadalje s povečanjem odzivnost pri starših ter večjim izražanjem lastnih čustvenih stanj pri otroku (Speltz, 1990).

Program Susan McDonough (1993) z imenom Interaction Guidance (IG) so razvili na Child Guidance Clinic v Los Angelesu in je namenjen družinam, ki načeloma ne iščejo terapevtske pomoči. Preusmeritev iz »zdravljenja « v »izobraževanje in ozaveščanje « je prek dekulpabilizacije staršev povzročila, da je program dosegel širši spekter družin, predvsem družine, ki zaradi stigmatizacije ne iščejo pomoči. Program se začne kot skupno odkrivanje in raziskovanje otrokovega vedenja, $\mathrm{z}$ obiskom na domu, ki mu sledijo formalna srečanja $s$ starši in otrokom v ustanovi. Na srečanjih, ki so posneta s kamero, se otrok igra sam ali s starši. Ti se med tem s terapevtom pogovarjajo o preteklem tednu ter si nato skupaj ogledajo posnetke in jih komentirajo. Cilj programa je spremeniti povezavo med vedenjem staršev do otroka in miselnimi procesi pri starših oziroma doživljanjem otroka, ki izhaja iz njihovega notranjega delovnega modela, s pomočjo katerega interpretirajo otrokovo vedenje. $\mathrm{Na}$ podlagi zaupnega stika s terapevtom starši postopoma sprejmejo drugačno, ustreznejšo in bolj sočutno razlago otrokovega vedenja in čustvovanja, kar pripelje do tega, da se na to vedenje tudi odzivajo drugače in bolj sočutno. Program je dokazano učinkovit za depresivne starše, starše, ki se upirajo drugim oblikam pomoči, starše z manjšimi kognitivnimi sposobnostmi in za starše otrok, ki imajo težave s spanjem, hranjenjem ali pretirano jokajo (Erzar, Kompan
Varna navezanost je lastnost odnosa.
Erzar, v tisku).

V zadnjih treh letih je Katarina Kompan Erzar s sodelavkami na Frančiškanskem družinskem inštitutu v Ljubljani razvila program pomoči mladim materam, ki vsebuje osem dvournih srečanj za matere, ki so na porodniškem dopustu in lahko zato obiskujejo srečanja skupaj z otrokom. Cilj srečanj je razviti in okrepiti sposobnost mater za netesnobno prisotnost ob otroku in sočasno razpoložljivost za otrokove signale in potrebe. Pot do te sposobnosti vodi prek soočanja mater $\mathrm{z}$ lastnimi skrbmi in dilemami, zlasti $\mathrm{v}$ zvezi s partnerjem in njegovimi odzivi na njeno materinstvo. Prav zato je $\mathrm{v}$ program vključeno tudi srečanje $\mathrm{z}$ očeti oziroma možmi teh mater, kar po njihovih izjavah močno pripomore $\mathrm{k}$ zmanjšanju napetosti in večji varnosti v vsej družini. Voditeljice in sodelavke programa so ob tem ugotovile, da ustvarjanje varnega prostora za delovanje in vodenje skupine, ki je tako občutljiva za napetosti in vplive okolja, zahteva od njih samih tako predhodno kot sprotno ustvarjanje čustvene povezanosti in uglašenosti (Kompan Erzar, Poljanec, Simonič in Novšak, 2008).

Vsi programi, ki se opirajo na teorijo navezanosti, izhajajo iz načela, da mora biti terapevtska in starševska drža do otroka ne samo rahločutna in odzivna, ampak tudi primerna njegovi starosti, saj le tako pripomore $\mathrm{k}$ otrokovemu duševnemu zdravju ter čustvenemu, socialnemu in kognitivnemu razvoju. Kakršnekoli metode ali oblike pomoči, ki vsebujejo elemente prisile, kaznovanja in čustvenega izsiljevanja ali 
poskuse spreminjanja vedenja pri otroku, ki so letom neprimerni, ker vsebujejo napačen fizični stik, so s tega vidika stranpot, ker ne gradijo vzajemne čustvene povezanosti med terapevtom in otrokom, ne vzbujajo zaupanja in ne pospešujejo usklajenega sodelovanja.

\section{SKLEP}

Današnja spoznanja o družini in odnosih v družini bi lahko strnili v naslednje postavke: a) vsak živi sistem, tudi sistem odnosov v družini, je celota med seboj odvisnih in povezanih delov, ki so šibkejši od celote; vsak sistem

Vsak otrok potrebuje varen temelj. je zgrajen iz podsistemov, ki jih ločijo meje ali razmejitve; vzorci vedenja $\mathrm{v}$ sistemu so krožni in nelinearni; sistemi se samouravnavajo in težijo $\mathrm{k}$ stabilnosti; $b$ ) otrok je najšibkejši člen družinskega sistema, ker se zgolj odziva na dogajanje v drugih delih sistema; otrok ni sedež nagonskih impulzov; c) odnosi so vzajemni, kar pomeni, da en član sistema ne more vplivati na drugega, ne da bi drugi vplival na prvega; $\mathrm{v}$ teoriji navezanosti to pomeni, da otrok ne more razviti sistema navezovanja, če ne sproži v skrbniku vzajemnega odzivanja njegovega starševskega sistema; $d$ ) regulacija afekta, ki jo teorija navezanosti opazuje v diadi, je v svojem jedru sistemska; ker se navezovalne potrebe prebujajo hkrati pri vseh družinskih članih, ali, drugače rečeno, ker te potrebe prebudijo v odraslih reakcije, ki imajo ozadje v navezovalnih izkušnjah v izvorni družini, je navezanost tipično sistemski in medgeneracijski pojav; regulacija afekta, ki spremlja navezovalno vedenje, se odvija za vse člane sočasno, kar je še posebno očitno $\mathrm{v}$ manj funkcionalnih družinah, kjer člani zaradi podobnih izkušenj doživljajo podobno stisko in je drug drugemu ne morejo olajšati, kar jih potegne $\mathrm{v}$ vrtinec obtoževanj in jeze.

Opazovanje in sočutna obravnava otroške nemoči in stiske sta bila glavni vir razvoja teo- rije navezanosti. Otroško trpljenje nas vedno znova opominja, da smo odrasli tukaj zato, da na to stisko damo ustrezen odgovor, torej, da najprej ustavimo nasilje in zlorabo, izoblikujemo tolažbo, poiščemo vir stiske in zagotovimo okolje, v katerem bo ta vir lahko preoblikovan in ustrezno zamejen. Naslednji korak je vzpostavitev varnih sistemov pomoči, ki bodo lahko delovali kot varno zavetje in trdno izhodišče za posameznikov zdravi razvoj. $\mathrm{Z}$ besedami Johna Bowlbyja iz njegovega dela $\gg \mathrm{A}$ secure base « bi povzeli, da vsak otrok potrebuje varen temelj, na katerem bo zmogel izoblikovati močan in učinkovit način soočanja z izzivi razvoja in način regulacije stresa, ki mu bo omogočal povezovanje $\mathrm{z}$ varnimi drugimi na varen način (Bowlby, 1988).

\section{LITERATURA}

Bowlby, J. (1969). Attachment, vol. 1 of Attachment and Loss. New York: Basic Books.

Bowlby, J. (1973). Separation: anxiety and anger, vol. 2 of Attachment and loss. New York: Basic Books.

Bowlby, J. (1980). Loss: sadness and depresion, vol. 3 of Attachment and loss. New York: Basic Books.

Bowlby, J. (1988). A secure base. London: Basic Books.

Cicchetti, D., Toth, S. L. (1987). »The application of a transactional risk model to intervention with multi-risk maltreating families«. Zero to Three, 1-8.

Erickson, M. F., Korfmacher, J., in Egeland, B. (1992). »Attachments past and present: Implications for therapeutic intervention with mother-infant dyads «. Development and Psychopathology, 4, 495-507.

Erzar, T., Kompan Erzar, K. (v tisku). Teorija navezanosti. Celje: Mohorjeva družba.

Fraiberg, S. (1967). »The origins of human bonds «. Commentary, 44: 47-57.

Fraiberg, S. (1980). Clinical studies in infant mental health: The first year of life. New York: Basic Books.

Hughes, D. (2008). Attachment-focused Family Therapy. New York: Norton.

Kobak, B. R., in Sceery, A. (1988). »Attachment in late adolescence: Working models, affect regulation, and perceptions of self and others «. Child Development, 59: 135-146. 
Kompan Erzar, K. (2008). Ljubezen umije spomin. Ljubljana: Brat Frančišek in Frančiškanski družinski inštitut.

Kompan Erzar, K., Poljanec, A. (2010). Rahločutnost do otrok. Ljubljana: Brat Frančišek in Frančiškanski družinski inštitut.

Kompan Erzar, K., Poljanec, A., Simonič, B., Novšak, R. (2008). »The Young Mother's Group«. Illinois child welfare Journal, 1.

Larrieu, J. A., Zeanah, C. H. (2004). »Treating infant -parent relationships in the context of maltreatment: An integrated, systems approach $\ll$. V: A. Sameroff, S. McDonough in K. Rosenblum (ur.), Treating parent-infant relationship problems. New York: Guilford Press.

McDonough, S. C. (1993). Interaction guidance: »Understanding and treating early infant-caregiver relationship disturbances «. V: Charles H. Zeanah (ur.), Handbook of infant mental health. New York: Guildford Press.

Schore, A. (1994). Affect regulation and the origin of the self. Hillsdale: Erlbaum.

Siegel, D. 2003. The developing mind. New York: Guilford press.

Speltz, M. L. (1990). »The treatment of preschool conduct problems: An integration of behavioral and attachment constructs «. V: M. Greenberg, D. Cicchetti in M. Cummings (ur.), Attachment in the preschool years: Theory, Research and Intervention. Chicago: University of Chicago Press. 